\title{
John Rawls' Theory of Justice: A Retrospection of Nigeria's Social and Politico-Economy Phenomena
}

\author{
Samuel S. Idowu \\ Department of Political Science and International Relations, Covenant University, Ota, Ogun State, Nigeria
}

\begin{abstract}
Nigeria as a country is characterised by a lopsided federal structure, and regionally based party - politics, plus other primordial sentiments of ethnic and religion that stand to hurt the existence of a just society. These foundational challenges make the possibility of an egalitarian community such that is capable of ensuring Nigeria's political and socio-economic development doubtful. Hence, this study undertakes a critical examination of Rawls' theory of Justice employing its assumptions to mirror Nigeria's social and political economy phenomena in other to glean its embedded lessons, primarily to enhance them. With historical research design and content analysis of secondary information, the paper found out that the country's constitutional provisions on human's rights are circumscribed by the political leadership to engender a primordial sentiment of ethnic chauvinism and religious bigotry to their advantages. The study recommends citizens' alongside NGOs intense demand for leadership transparency and accountability amongst others to ensure social, political and economic development with harmonious co-existence at the same time.
\end{abstract}

Keywords: Economic; Rawls; Nigeria; political; Social; Phenomena

DOI: $10.7176 / \mathrm{JAAS} / 63-02$

Publication date: April $30^{\text {th }} 2020$

\subsection{Introduction}

Attaining better living conditions for citizens in society has been identified as the utmost responsibility of a responsible government. Towards achieving this goal, political thinkers have generated, and still generating, suitable frameworks, considered appropriate for every human society, though with varying contextual applicable differences but seems nearer to an ideal polis (using Aristotle's ancient Greek state connotation), emergence. A common denomination of political theorists from the classical writers, such as Plato, to modern thinkers like Hobbes, seems to be a quest for the enthronement of political leadership with capacity for societal socio-economic advancement. Put differently, Plato canvasses for the philosophical king, and Hobbesian's social contract theory are geared at actualizing a progressive and an egalitarian grouping of people. Hence, this largely accounted for the diverse logics advanced by philosophers to arrive at this destination with the masses' welfare standing out as the integral feature, often central even amidst growing plural society sometimes characterised by elements of conflicting morals, opposing beliefs and diversity of social orientations.

In this line of reasoning, John Rawls (1971), a Professor of Philosophy at Harvard University notes in his book "A theory of justice" published in 1971 and his corresponding further explanatory book titled, "political liberation in 1993" alongside other explanatory articles, that fair and distributive justice is the fundamental basis for an ideal society; and it is a significant identity of a well ordered political entity (cited in Erin, 2014). This suggests that the individual's liberty and equality with prioritization of their common good are expected to underpin a country's social institution's policy thrust. Additively, the policy should embody a maximum consideration for all citizenry, especially the less well-off or disadvantaged groups. In this regard, can one maintain that this is obtainable across countries in the global space, especially in developing climes like Nigeria?

Moreover, Nigeria's situation posits by Akinboye and Anifowose (1999) as a country based on a foundation characterised by a lopsided federal structure, ethnic consciousness and rivalries, regionally-based party politics and perverted indigenous governance and cultural ethos aggravates concerns for the possibility of having fairness and equity being entrenched. And with this background, is distributive justice with its attendant political and socio-economic development realizable from Nigeria's configuration? Hence, what seems like a misalignment with an ideal political system informed the examination of the extent of John Rawls' theory applicability to Nigeria milieu. Therefore, this paper examines the core principles and plausible components of Rawls' theory, and some of the confronting criticism against it as argued by scholars while placing it beside Nigeria's phenomena. It proceeds to appropriate strengths embedded in Rawlians' justifications to interrogate Nigeria's framework.

The paper is divided into five sections. The first section is the introduction and the succeeding section states the research method. Discussion of Rawls' theory of justice occupies the third section while lessons to be appropriated to Nigeria are analysed in the fourth section and the fifth section concludes the work.

\subsection{Research Method}

Historical research design is considered an appropriate method suitable for this paper. This is hinged on the nature of the study which is a critical evaluation or examination of John Rawls' theory of justice requiring an inquiry into 
documented data. Moreover, According to Eneanya (2012: 78) 'Historical type of research is constructed for an inquiry into the past events and traces they have left, past experience, trends of occurrence in the past, collective roles and individual roles, as well as institutional roles in a social phenomenon... The data collected undergoes certain evaluation, synthesis, and critical analysis before the knowledge discovery is made and a logical conclusion is drawn'

From the above submission, qualitative secondary data sources, which are often historical, though generated from credible sources, are obtained from the literature to prosecute this research while being subjected to textual analysis.

\subsection{John Rawls' Theory of Justice: An Interrogation}

Rawls' theory is generally synonymous with liberty, equal right, and citizens' welfare anchored on the impartial public allocation of common goods or benefits and burden by the managers' of the social institutions (Rex, 2014). Implicitly, the theory shares neo-liberal socio-political and economic tenets that promote individual liberty. Nevertheless, salient principles underpinned Rawls' theory providing forces for its explication and propagation. These are also the canons that elucidate Rawls' political thought, the premise on which the emergence of a just society is anchored. It is tagged "Principle of Distributive Justice of Political Conception of Justice" (Erin, 2014). Hence, an overview of these principles would offer insight into the thrust of the theory with the extent of its relevance to Nigeria's context which is the focus of this study.

\subsection{Principle of Liberty}

The principle of liberty assumes that a just society begins with the freedom of its citizens to enjoy and exercise their inalienable equal rights. The basics of this liberty are associated with the freedom of speech, right to vote and be voted for, religion protection amongst others. In the words of Rawls, it is aptly stated thus: 'Each person is to have an equal right to the most extensive scheme of equal basic liberties compatible with a similar scheme of liberty for all and in this scheme the equal political liberties and only those liberties, are to be guaranteed their fair value' (Rawls 1999:60). Deductively, Rawls submits that human rights are absolute; it should not be abused; and, it is meant to be elastic except if restrained to guarantee the liberty of citizens.

Further to this, indices of the liberty, in this sense, are inalienable right of every citizen in an organized state. But, in reality, could these assumed rights of a citizen not relative in the sense of the provision of immunity clause preference for elected executive officers like Mr. President in a country's constitution as well as the elite considerations in the policy choices and implementations associated with the many of the developing countries, especially Nigeria? Hence, there seems an existence of a right's chasm between the political, other elite classes and the populace, limiting the degree of liberty applicability in a polity and, consequently, vitiating its virtues.

\subsection{Principle of Social and Economic Inequalities}

As a complement to the principle of liberty, Rawls (1971) maintains that equality of citizens must be extended to or be reflected in their social well-being, and economic life and equal opportunity must be charted by social institutions to promote an equal distribution of primary goods, which according to Rawls are things that every citizen is presumed to want regardless of his or her specific goals in life. He specifically and forthrightly described the primary goods thus: "what persons need in their status as free and equal citizens and as normal and fully cooperating members of society over a complete life' (Rawls 1999a: 54, 87).

The import from this argument is in two folds. First is that the primary goods are essential for human sustenance and, as such, must be provided by a responsible government. Second, the role of government as a public figure or institutions superintending the state is crucial not only as the sole determinant of the degree of citizens' cooperation but also the fairness of the distribution of goods through which inequality would be eliminated or, at least, be degraded in the society. But, naturally, it seems very difficult for a logical mind not to be skeptical about the feasibility of this in a heterogeneous society where primordial sentiments often overshadowed every sense of objectivity in the management of the superstructure institutions.

However, in what appears like a means of circumventing inequality from the government end, Rawls articulates conditions guiding the choice and decisions of representatives of the public institutions when he forcibly argues that social and economic inequalities are to satisfy two conditions as stated thus:

First, they must be attached to positions and offices open to all under conditions of fair equality of opportunity; and second, they are to be the greatest benefit of the least advantaged members of society...Every member of the society is entitled to access the public office if so desired that is, there should be no disqualifying qualifications and any form of discriminatory basis or factor. If there is any, it must be at minimum attainable by many, if not all, eligible citizenry. It is a great height of political equality that is mindless of whatever individual social or economic class or status is in the state (Rawls, 1999a:60).

As a corollary, and stressing the means to attainment of political equality, Rex (1994:746) avers thus: 'And 
this equalizing of the opportunity to count politically is to be delivered through (a) limits on campaign spending or (b) government funding of campaigns, or (c) public subsidy (or a mandate for ready and inexpensive availability of airtime) to candidates and political parties and other relevant points of views'

Arising from Rawls and Rex argument on strategies for entrenching social and economic equality by assurance of availability of political platform through the instrumentality of the right to be voted for as an element of the principle of liberty are what appears as discountenance of varied or competing political orientations, ideology and influence of individuals (social and economic) status in a political game. In reality, Rex advocates for the accommodation of the individual's input in the political process as a "fair value" in a democratic scheme of citizenship seems utopian as the marketing of superior opinions is a vital political strategy for canvassing for votes by politicians.

Moreover, it sounds a lofty explanation that can, at best, be obtainable in an advanced democracy where the assumptions and applications of Rawls principles of social and economic equality origin are somewhat traceable to. But in some young democracy, like Nigeria and many African states, where competition for the public offices is approximately a zero-sum-game of winners take all, and for the primary purpose of denying opposition groups a minimum access to state-owned apparatus, such as media outfits, a justification for "fair value" and access norms of political equality principle in a concrete sense appears illusory. For instance, Biereenu-Nnabugwu (2015) pictures Nigeria's politics as a business with good economic returns because political class perceives the state as a "wealth mines" meant for plundering. However, in a contest for the plundering of the national commonwealth by the political institutions' administrators in Nigeria, the socio-economic equation might be difficult to balance with political equality or representation.

In addition, two major beliefs are identified as the rationale for stressing open access to public institutions by Rawls (cited in Erin (2014:5). The first is the fact that social institutions affect our conditions of living and values system in a great way. In other words, our socio-political and economic environment, and other areas of community life are highly susceptible to the political institutions' occupants' tastes, preferences, whims, and ideological disposition. And the second states that the institutions largely determine the society or citizens' expectations in terms of the benefit outputs and values attached to such. March and Simon (1993), Eister (1983), March and Olsen 1989 (cited in Rex, 2014:6), nevertheless lucidly sum up the citizens' expectations as: 'to give to all according to merit or effort. Furthermore, we are malleable: institutions characterize even our assessment of the benefits and burden such institutions provide'

It is noteworthy that the second condition encompasses a considerable disposition of the public office holders to the less-advantaged members of the society in the crafting and drafting processes of policy, more importantly on the distribution of the community commonwealth. Rawls (1993) refers to this as "difference principle" meaning that only inequalities that are to the advantages of the least advantage are to be tolerated in the society (cited in Rex, 1994:751). As such, it underscores the importance of maximizing the benefits of the commonwealth across its length and breath, high and low, rich and poor or every category of the society regardless of the ethnic, racial or religious leaning. But, as it suggests, not without a deliberately programmed conscious effort to favour the least well-offs by the public officials. In this sense, the poor are preferentially considered as the beneficiary of the national wealth, and the least affected of the society's burdens at the same time.

The difference principle, on the other hand, implies that irrespective of what might have been the cause of the least fortunate fortunes within the circle of either lack of natural or acquired skills, laziness, poor choices or any other human-error induced misfortune, such should be discarded by the state in the pursuit of the social welfare agenda. Therefore, the researcher argues that the difference principle failure to holistically discern or define the least advantage citizens tends to promote indolence, discourage hard work, and discount potentials manifest of individuals making up the state, which is fundamental to its robust development.

Meanwhile, on a specific note, Erin (2014) accuses Rawls of not been decisive of some of the citizens' abilities while Sen (1980) critique the submission for ignoring the personal differences of people with disabilities as first among others to access the public goods. Although Rawls (1999a) response to the argument against who is the least unfortunate is that it requires identifying a representative of the different distribution of income and wealth category and as well singled out the least advantaged ones among them, but this appears too simple a criteria. Also, how, and the rationale or yardstick Rawls has in mind or expected to be applied in identifying the least advantaged based on levels of income in the society are not adequately explicated. Nonetheless, undoubtedly, there is hardly a defined measure(s) to this effect that would not more or less generate new ripples of controversy.

Flowing from the Rawls' difference principle x-rayed above is the degree of its practicality or accurate applicability across the national boundaries. In Nigeria, for instance, determining a least fortunate group might be difficult because of the conflicting statistical data from the government, private sectors, and international institutions on poverty ratio, better life indices, and other economic measuring indicators which is also applicable to most of the developing states. The conflicting figures may be as a result of poor data sources, manipulations or interpretations based on differing perspectives. However, given the importance of information in this case, how can the government be able to properly design and implement a robust and an even welfare policy for the populace? 
Also, how possible it is for the political leadership class, described by Ferreira (2009), as obsessed with parochial interest, not to stand like an army of the tribal or regional temple, and averse to offering political education on possibilities of national economic development to ensure an impartial distribution of the social goods? Be that as it may, since Nigeria manifest the features of ethnicity, religion, and other non-nationalistic sentiments in the management of the state's apparatus and resources, the difference principle appears applicable in this context.

\subsection{Theory of Justice Underpinnings}

John Rawls set premises on which the theory of justice hinges and which provides footing for its proposition for a fair and just society. Though it has been roundly criticized from different perspectives of many scholars yet it is deemed appropriate as a useful tool or instrument in attaining an egalitarian community. Three basic presumptions of Rawls on which the principles earlier discussed leverage on are:

i. $\quad$ Veil of ignorance;

ii. Behavior assumptions; and

iii. Social primary goods

\section{i. Veil of Ignorance}

Distributive justice is attainable only through the institutions, either political or social considered as necessary agents in an organized society. Hence, they have a great influence on the lives of people, most importantly, the spread and amount of benefits or burdens flowing to the citizenry. This is a legitimate business confer on the institutions with the citizens' consent. This seems to picture the social contract orientation influence on Rawls, albeit, with a departure from its operational tenets as articulated in the theory of justice.

Nevertheless, Rawls' (1997) submits that there exist an equal notches of social primary orientation by all citizenry, which, to a large extent, is predicated on the social institutions, and posits that decisions or choices must be made without a prior understanding of the decision makers' characteristics (such as sex, abilities, position or consequent experience) which may be negative or positive. Bojer (2000:38) sheds more light on this assumption thus: 'the individuals' lack of knowledge about their backgrounds, positions and personal traits is a way of conceptualizing impartial justice'. But the author maintains that someone cannot be emptied or stripped-off of his experience, both of the past knowledge as well as the social awareness influence in decision making. This, in the real sense, portrays the almost mere idealistic nature of Rawls' veil of ignorance assumption.

Furthermore, in reality, while experience appears as part of the background factors that inspired and dictates the direction of individuals' decision, it likewise largely shapes his interest. Thus, personal interest almost remains difficult to eliminate in decision making, though might be modified through mutual consensus or compromise in collective instances. In Addition, Rawls further argues that for this choice to be fair, since they cannot determine their fate, the least-disadvantaged welfare and benefit must be given the highest priority which are referred to as the 'decision behind a veil of ignorance' reiterates the acknowledgement of the existence of a class society that needs to sway the benefits to the poor masses.

From Rawls' line of thought on assumption that collective decision would be least subjective, it suggests that he factored-in nether class and thus would be fair to all when the policymakers deprecate personal interest for considerations of the less-privileged simultaneously. This underscores the strategic positional occupation of the building of institutions and its leadership as the bedrock in the development of the political and socio-economic frontiers of every political system. However, with the incidences of human natural tendencies for greed, selfishness, and similar vices, would there emerge an institution's managers possessing these qualities innately except learned or acquired through political socialisation in a polity? Nevertheless, since an ideal condition seems unattainable, this might be an additional contributive factor to Nigeria's defective structure and prevalent of the centrifugal features and forces observed by scholars.

\section{ii. Human Behavior Assumptions}

Human behavior tendency as reasoned by Rawls (199b) is geared towards the emergence of a state with a sense of justice and rationality. A right sense of justice depicts that no individual would deny any perceived rules, principles or things as unfair or unjust when they are not. It assumes also that no one is not reasonable enough to decipher between just and unjust issues in life. Thus, one can infer that it is a moral or ethical issue assumption which cannot perfectly suit every society as what is morally right in a given society may not be right in another. For instance, polygamy is morally wrong in many western countries but not in most African states due to their cultural orientation or practices. Erin (2014) observes thus: 'Note that this premise is normative; the theory thus does not attempt to justify moral consideration out of self-interest alone'. The submission seems to highlight normative moral orientation influence on Rawlsian's thought.

Likewise, Rawls' human rationality position is rested on the rational decision capacity of every individual. In other words, he assumes that no one would naturally make an irrational or illogical decision. It implies, therefore, that choice, appearing unsound, made by men did not originate from their right senses or intuition judgment, and should be so taken or be made to undergo revision. Expectedly, both the leaders and the led decisions are not prone to treading faulty lines of undue personal considerations and linear thought pattern. And, additively, it 
suggests that if occupants of the social institutions truly apply this tenet in arriving at policy decisions, chances of Rawls' principles of justice manifestation becomes brighter, thus limiting the imposition of individual idiosyncrasies in the public domain. This pattern of thinking is what Rawls refers to as "reflective equilibrium" (Rawls 1999c).

However, in contrast to John Rawls' rational human behavior assumptions, many irrationally pattern of human behavior that abounded in virtually every community ranging from theft, lying, betrayal of public trust, financial misappropriation, etc, appear as an anti-thesis. Hence, it implies that cases of corruption prevalent among leaders that occupied the political institutions in some developing economy negate the thrust of a rational human being. In Nigeria, for example, Folarin (2014) submits that grand corruption festers in Nigeria from the private firms to public-political, bureaucratic-to military formations and other institutions such as media and entertainment with its deleterious impact on national social and economic life. Rationality, in this sense, is relative and might be interpreted based on the circumstances or prevailing situation. Therefore, human being appears as a complex being, as posit by the behavioural school of thought in the management and social sciences, appearing not only complex or difficult to predict but likewise rationalize any perceived irrational decisions, choices, and even behaviour.

\section{iii. Social Primary Goods}

A common and equal benefit is assumed to flow across every member of the society which Rawls (1999c) calls primary goods through the distribution channel of the social or political institution. The social goods are essential services that are indispensable to the citizens' welfare, well being and societal sustenance. In the real sense, they seem to be an aggregation of government policy output that is primarily meant to serve the citizen's demands with the expectation of having their support in return as depicted in David Easton political system theory analogy. It should be noted that the institutions posses the reservation of distributing the goods, though as expected, in accordance with the existing norms and expectations of the citizens.

Nonetheless, it is worthy of note that the assumption of social primary goods is also critique on the premise of being ambiguous or the plural nature of what social primary goods denote as something that possesses a challenge to the fairness of its distribution. Although Rawls (1999a) defines it as political, economic and social benefits, as observed earlier, it does not encapsulate the obtainable limitations of these goods in detail. For example, the political good of fundamental human rights is obtainable in most countries' constitution that endorses the United Nations' Universal Declaration on Human Rights of 1948 which equally stipulates limitations to some of these natural rights. But, how can one subtract the limitations to human rights from its benefit in the practical term? A case in point is Nigeria's 1999 Constitution (as amended) that recognizes right to vote at age 18 but states categorically differing ages as the eligible time to be voted for into the public offices, thereby disenfranchising citizens below the benchmarked ages from vying for the elective position.

Similarly, an individuals' preference is another determinant factor, to some extent, of its most needed primary goods. For instance, what constitutes the primary good of a farmer in a country-side, e.g. access to farm inputs and the market for his products in terms of a good road is quite different from that of a sick fellow that require good medical attention. What the institutions' decision-makers need do in such situation, according to Rawls, is to ensure an equal and just allocation of resources, and determine an approximate representation of the leastadvantage position in similar situation or group. While this is aptly stated thus: 'one suggestion is to count those people with less than half the median income as the worst off' (Rawls 1999a:84), how would the government determine the disadvantaged where both categories of the citizens are earnestly expecting government intervention? It seems almost impracticable in the scenario described above.

Also, Kymlicka (2002) observes a possibility of subsidizing expensive desire for leisure in a situation where Mr. A chooses to be more frugal in spending or work harder while Mr. B contrasted both but still enjoy the benefits of the least advantaged at the expense of Mr. A. This is a probable instance that is sometimes difficult to expurgate in a polity making social goods more amenable to subjective interpretation.

\section{John Rawls' Theory of Justice: Lessons for Nigeria}

This section of this study undertakes an exploration of discernible lessons embedded in the Rawls' theory of justice that is capable of enhancing Nigeria's socio-economic and political turf. The essentiality of this is premised on the objectives of this paper, and conviction that plausible lessons would add-up to the body of veritable inputs for national restructuring and corpus knowledge at the same time.

Firstly, creating an egalitarian society in Nigeria begins with embracing the principle of liberty. Thus entrenching equal rights in the constitution should be taken beyond the rhetoric to ensuring the upholding of such that create an equal level playing ground for the entire citizenry and in the conduct of the political and socioeconomic affairs of the nation-state.

The perception of an average Nigerian masses, that seems not to suggest an existence of 'we-feeling' mindset cum consciousness, would be disorientated under a new firmament of shared sense of equality in every aspect of National life, more importantly, before the eyes of the laws of the land, if even treatment is entrenched. As 
observed, the existence of the tendency for social discrimination, premised on economic or political class status would more likely experience a downward trend, and possibly lost its psychological grip on most Nigerians.

Consequently, the hitherto constrained political space ravage, according to Davies (2014) by money politics phenomenon, whereby rich politicians use the money to sway the support of electorates from opponent to their side and the manifestation of an unequal chance of party politicking and marginalization of most minority ethnic groups from accessing the central political office would be terminated. Similarly, according to The Punch (2014), the lopsided economic opportunity in favor of the nouveau riche but against the less-privileged citizens that engender further social inequality, as it appears; and ethnic discrimination in the political and social circles, a trend observed by Non Indigene Congress (NICO), a Non-Government Organization (NGO) in Nigeria that also kicked against the practice of discrimination against non-indigene of a state during recruitment exercises in some states of the federation would decline sharply in value if not obliterated.

In addition to the ethnic considerations, the deep-seated influence of religious sentiment-social institution-on the political office-holders (both elected and appointive), is weakening an objective application of equal rights. For instance, Omojuwa (2014) encapsulates this thus: 'in 2015, Nigerians will be voting for religious leader and his or her deputy. This is not the first time religion has played a part in the run-up to elections in Nigeria...' Obviously, religion has been playing a significant role in the skewing of electorates' perception in the electioneering process and acceptability of candidates based on faith sentiment. Aside veiling the electorates' right senses of making choice of political leaders at poll based on merit or competence, it also betrayed the spirit of secularity expressed in the country's constitution portraying the political class as circumscribing the constitutional provisions aimed at ensuring an egalitarian society to fester ethnic, religion and similar dividing elements to their advantage.

Hence, except the anti-equality tendencies are tactically and consciously expunge from the spirit, letter and operations of Nigeria's constitution, which set guidelines for the citizens' rights in both social and political platforms, equality status would remain almost inertia, exist only in principle, become a mirage and, elusive in practice.

On the principles of social and economic inequalities, premised on the need for equal access to social institutions saddled with the responsibility of managing and distributing the country's resources, there is a greater demand for good attention from the political leadership class. Annihilating factors such as sit-tight mentality, oppressive governance and all forms of indecent leadership traits misrepresenting good governance need to be eliminated, if possible, or at least play down in policy-making and implementation processes in Nigeria.

Furthermore, the political institutions' leadership should rise to the need of ridding themselves off of ethnic, religion, party, sectional interest or primordial sentiment to project a patriotic public figure image before the entire citizenry. With this kind of a neutral mind-set can policy decisions and executions be made to reflect the populace expectations especially, that of the less well-offs. And as well, the concept of virtues of 'veil of ignorance' could become operational, at least to a reasonable extent. Similarly, Nigerian masses should seize every available outlet to articulate their interest to acquaint political leadership class with their demands while the less disadvantaged groups' demands are given additional awareness by the civil society groups and Non-Governmental Organisations (NGO). In this regard, the print, electronic and social media outlets need to be explored to air their grievances or concerns while the masses employ their voting right and power to register their satisfaction or otherwise during the polls as well as demand for transparent and accountable governance from the political institutions' managers.

Also, immunizing the social and political institutions against abuse is germane to the attainment of distributive justice in Nigeria. Given the harrowing consequence of poor leadership on the country in terms of stunted political and socio-economic growth, strengthening the institutional legal frameworks alongside annotation on social reformations simultaneously to reverse the negative trends appears non-negotiable. The negative narratives connected to the national management lapses and vices are sufficed to intensify effort towards building virile socio-political institutions and enthronement of competent persons in leadership positions. For instance, the editorial of one of the Nigerian's daily print media, The Punch newspaper (March 27 ${ }^{\text {th }}, 2014$ ) entitled 'irresponsible neglect of social mineral' asserts that it is a sad paradox of the Nigerian story that the country that is so richly blessed with mineral has for four decades neglected them all to rely virtually exclusively on oil and gas for foreign income. In this regard, citizens' need to lead the vanguard in other to reverse the above farce, and fulfill the mandate, captured in the word of Uwazurike (2008:63) as: 'The task of the present democratic dispensation must then not be lost sight of - the need to re-take the state in Nigeria, re-Africanize it, makes it the property of the people. The first task is to be in the service of the people's welfare'.

As a complementary effort to the citizens' drive towards an activating a progressive institutions, the Nongovernmental Organizations (NGO) and private firms should not only mobilize the citizens but intensify and deepen advocacy for fair distribution of benefits to grow business, and its sustainability with a view to engendering a conducive environment and enacting business-friendly policies. However, Rawls was critique by Erin (2004) for not including the NGO and private firms as part of the social institutions and stakeholders which, but as revealed in this study, are necessary stakeholders in the building of harmonious and virile co-existence political 
system in Nigeria.

\section{CONCLUSION}

John Rawls' political theory of distributive justice is making immense contributions to the wealth of existing theories towards improving states' political structures, process, practices amidst variegated opinions, ethnics, and other pluralistic elements in global societies today, especially in Nigeria's context examination in this paper. Specifically, the principle of equality has further deepened human liberty beyond western the western-cultured democracy to a new democracy like Nigeria, and by extension, Africa and developing countries as revealed in this study.

This work maintains that when the lessons derived as applicable from Rawls' theory to Nigeria's context are faithfully applied, an emergence of a better society is imminent in no distant time. This is the significant contributions of this paper to the body of knowledge. However, Rawls' theory might not have been exhaustively analyzed; therefore it is open to further study and critique.

\section{REFERENCES}

Akinboye, S. and Anifowose, R. 1999. Nigerian Government and Politics. In R. Anifowose and F.Enemuo (Eds.), Elements of Politics (pp.238-260). Revised Edition, Lagos: Sam Iroanusi Publication.

Biereenu-Nnabugwu, M. (2015). Lumpendemocracy and the Dialectics of Insecurity in Nigeria. Studies in Politics and Society Vol. 2, No 2 259-328.

Bojer, H. (2003). Distributional Justice. Theory and Measurement. New York: Routh- ledge

Davies, A. E. (2014). Money Politics in the Nigerian Electoral Process. In R. Ajayi and J.O. Fashagba (Eds.) Understanding Government and Politics in Nigeria. Ilorin: YesterTodayRrow Consult.

Elster, J. (1983). Sour Grapes: Studies in the Subversion of Rationality. London: Maison DesScience De L'Homme Cambridge University Press.

Ember, C.R. and Levinson, D. (1999). The Substantive Contributions of Worldwide Cross-Cultural Studies Using Secondary Data. Behavior or science Research 25 1-4 79-140

Eneaanya, A. N. (2012). Research Methods in Political Science and Public Administration. Lagos: University of Lagos Press.

Erin, K. (2014). John Rawls Theory of Justice as Fairness: A Restatement. Retrieved on $9^{\text {th }}$ March, 2019 from http:www.worldcat.org/title/justice-as-fairness-a-restate ment/oclc/45388455

Erin K. (1994). Rawls New Theory of Justice. Retrieved on 24 ${ }^{\text {th }}$ April, 2015 from http.// scholarship.kentlaw.iit.edu/cklawreview/vol.169/is s/318

Federal Republic of Nigeria, (1999): Constitution of the Federal Republic of Nigeria (As Amended).Lagos: Federal Republic of Nigeria Press.

Ferreira, A. (2009). The Struggle to Develop Nigeria. Abuja: Panaf Publishing Incorporated

Folarin, S. (2014). Corruption, Politics and Governance in Nigeria. In R. Ajayi and J.O. Fashagba (Eds.) Understanding Government and Politics in Nigeria. Ilorin: YesterTodayRrow Consult.

Kymlicka, W. (2002). Contemporary Political Philosophy. London: Oxford University Press.

March, J. G, and Herbert A. S. (1993). Organisations. London: Blackwell 2nd Edition.

March, J. O. Johan P. O. (1989). Rediscovering Institutions: The Organisational Basis of Politics. New York: Free Press.

Rawls J. (1999a). Collected Papers Samuel Freeman (red) Cambridge, Mass: Harvard

Rawls, J. (1971). A Theory of Justice Cambridge Mass: Harvard University Press.

Rawls, J. (1993). Political Liberalism: New York: Columbia University Press.

Rawls, J. (1997). The Idea of Public Reason Revisited. University of Chicago Law Review, 64 Summer: 765-807

Rawls, J. (1999b). The Law of Peoples Cambridge, Mass: Harvard University Press.

Rawls, J. (1999c). Social Unity and Primary Goods. In John Rawls Collected Papers S. Freeman (Ed): London. Harvard University Press 359-387. Retrieved on 24 ${ }^{\text {th }}$ April, 2015fromhttps// www.gbv.de /dms/spk/sbb/toc/254360696.pdf

Rex, M. (1994). Rawls New Theory of Justice. Retrieved on 24 ${ }^{\text {th }}$ April, 2015 from http:/ / scholarship.kentlaw.iited.edu/ck law review vol69/iss 3/8.

Sen. A. K (1980): "Equality of What?” Choice, Welfare and Measurement. London: MIT Press

The Punch (2014): Irresponsible Neglect of Solid Mineral. The Punch, March 27 $7^{\text {th }}: 2014$, Page 18.

The Punch, (2014). Group Frowns on Job Discrimination Against Non-indigenes. The Punch, September $7^{\text {th }} 2015$, page 43.

University Press.

Uwazurike, P. C. (2008). At The Crossroads and Beyond: Another Nigeria is Possible New York: Concept Imprint 